

KALANGWAN

JURNAL PENDIDIKAN AGAMA, BAHASA DAN SASTRA

Vol. 9 No. 2 September 2019

\begin{tabular}{|l|l|l|}
\hline p-ISSN : 1979-634X & e-ISSN : 2686-0252 & http://ejournal.ihdn.ac.id/index.php/Kalangwan
\end{tabular}

\title{
INTERPRETASI BHATARA KALA \\ SEBAGAI PEMBATAS ETIKA BUDAYA BALI \\ DALAM LONTAR KALA-PURANA
}

\author{
Oleh : \\ I Wayan Mandra \\ Institut Hindu Dharma Negeri Denpasar \\ E-mail: wayanmandraihdn@gmail.com
}

Diterima 17 Juli 2019, direvisi 15 Agustus 2019, diterbitkan 2 September 2019

\begin{abstract}
Lontar Kala-Purana merupakan sebuah geguat atau dasar yang jelas (indik-indik) yang dipergunakan masyarakat Bali untuk melakukan panglukatan pada setiap orang yang terlahir pada saniscara (sabtu) wara Wayang. Ini merupakan satu bentuk refleksi yang secara nyata merupakan perpaduan antara tattwa, etika, upacara secara simultan dan dibungkus dengan budaya Bali. Jika berbicara masalah tattwa, maka narasi Kala-Tattwa sudah memberikan penjabaran bagaimana Bhatara Kala, yang merupakan personifikasi dari sebuah kekuatan (energi) penghancur merupakan sebuah hal yang badai. Bahkan dalam beberapa kitab mantra samhita, Upanisad, maka "Kala" merupakan menghancur yang agung. Sebab waktu, adalah kekal dan yang menghancurkan. Kitab Bhagavadgita sendiri menyatakan bahwa diantara yang menghancurkan, tidak ada yang lebih baik selain "Kala" (waktu) itu sendiri.
\end{abstract}

\section{Keywords: Bhatara Kala, Etika Budaya Bali, Kala-Purana}

\section{PENDAHULUAN}

Lontar Kala-Purana merupakan sebuah geguat atau dasar yang jelas (indik-indik) yang dipergunakan masyarakat Bali untuk melakukan panglukatan pada setiap orang yang terlahir pada saniscara (sabtu) wara Wayang. Ini merupakan satu bentuk refleksi yang secara nyata merupakan perpaduan antara tattwa, etika, upacara secara simultan dan dibungkus dengan budaya Bali. Jika berbicara masalah tattwa, maka narasi KalaTattwa sudah memberikan penjabaran bagaimana Bhatara Kala, yang merupakan personifikasi dari sebuah kekuatan (energi) 
penghancur merupakan sebuah hal yang badai. Bahkan dalam beberapa kitab mantra samhita, Upanisad, maka "Kala" merupakan menghancur yang agung. Sebab waktu, adalah kekal dan yang menghancurkan. Kitab Bhagavadgita sendiri menyatakan bahwa diantara yang menghancurkan, tidak ada yang lebih baik selain "Kala" (waktu) itu sendiri.

Konteks inipun, pengertian kata "Kala" dapat menjadi sebuah hal yang merujuk pada energi, atau kekuatan kosmis yang menjadi satu spirit fundamental secara universal. Oleh sebab itulah, mengapa tradisi ajaran dan pemujaan terhadap Bhatara Siwa di Bali juga menempatkan Bhatara Kala sebagai putra Bhatara Siwa. Secara harfiah, jika seseorang merujuk pada pemujaan kehadapan Paduka Bhatara Siwa, maka eksistensi kekuatan kosmis itu sendiri menjadi sangat penting. Kita ketahui bersama, bahwa Paduka Bhatara Siwa sendiri merupakan penguasa jagat raya dengan kekuatan penuhnya. Bahkan untuk menghancurkan (mendaur ulang dalam pengertian yang sempurna) sekalipun, maka energi Paduka Bhatara Siwa ini menjadi titik sentral.

Berdasarkan itulah, ketika proses pendaur ulangan dunia, maka Paduka Bhatara Siwa menari-nari dalam tarian kosmis yang disebut dengan Tandava Nrtya Siva Nata Raja. Ada banyak bentuk paripurna dari kekuatan Paduka Sang Hyang Siwa yang merealisasikan kekuatan, dan karena dalam agama Hindu, Sang Hyang Siwa menempati posisi sebagai pelebur, maka sebagian besar iconografi tentang Beliau dibuat sedikit menakutkan.

Tidak hanya Bhatara Kala yang diiconografikan dengan bentuk yang sangat menyeramkan dalam konteks ini. bahkan bentuk paripurna Paduka Bhatara Siwa sendiri pun sangat menakutkan, seperti Sang Hyang Virabadra. Secara simbolik, hampir tidak ada perbedaan yang terlihat dari perwujudan Sang Hyang Virabadra dengan penggambaran Bhatara Kala dalam lontar Kala-Purana. Namun perbedaannya adalah, Paduka Bhatara Hyang Wirabadra tercipta karena kemarahan dari Sang Hyang Siwa sendiri. Sedangkan untuk Bhatara Kala, dalam lontar Kala-Purana tidak dinyatakan demikian. Tetapi inti dari semuanya adalah Paduka Bhatara Siwa dalam konteks beragama Hindu di Bali merujuk pada Dewataning penguasa segala macam jiva (atma) atau dengan istilah lain "Ngamongin atma". Bahkan karena itu juga shkti dari Bhatara Siwa sendiri juga direalisasikan dalam wujud Maha Durgha Dewi.

\section{PEMBAHASAN}

Lontar ini jelas sekali menggambarkan bagaimana Bhatara Siwa menjadi sutradara agung untuk setiap jalinan peristiwa. Jadi tampaknya naskah ini tidak berbicara narasi yang omong kosong belaka, ada latar belakang sejarah yang jelas terjadi di sana, dan ketika seseorang mulai meragukan kebenaran dari setiap bhisama yang terdapat dalam narasi lontar Kala-Purana ini, maka akan ada saja konsekwensinya yang datang entah cepat atau lamban. Bisa saja, kerangka berpikir ini dan memiliki pandangan bahwa apapun yang dinyatakan dalam lontar ini hanyalah sebuah multiinterpretasi dan imajinasi dari penulisnya. Tidaklah mungkin karena waktu kelahiran di saniscara (sabtu) wara wayang, seseorang tadah Sang Hyang Kala.

Inilah yang perlu kita luruskan sekarang, sebab pengertian tadah Kala, sudah mengalami sebuah evolusi sesuai dengan perubahan paruh yuga. Manusia tidak dapat lagi menyaksikan secara mata telanjang bagaimana rupa Bhatara Siwa dan Sang Hyang Kala. Tetapi bukan berarti yang tidak dapat kita lihat itu tidak ada. Ada banyak dimensi ruang dan waktu yang tidak kita pahami karena kemerosotan kualitas spiritual manusia. Setelah itu, pengertian itu dapat berubah menjadi energi yang memenuhi ruang, sebab Kala itu sendiri juga waktu. Apapun bentuk aktifitas manusia bahkan umur sekalipun sangat ditentukan oleh waktu. Lalu bagaimana mungkin manusia dapat lari dari waktu (Kala)? Terlahirnya beberapa orang yang menempati wara Wayang, bukan berarti kutukan. Melainkan sebuah jalan pembebasan yang didapat karena banyak hal. Sebab pembebasan itu didapat bukan oleh 
kesenangan dan hidup tenang, melainkan penderitaan berat.

Bahkan seseorang yang sadar akan pengertian itu, meninggalkan kesenangan dunia dan membuat badannya sendiri menderita (puasa tanpa makan minum dan bertapa) hanya untuk mencapai pembebasan semata. Jadi orang yang terlahir di hari itu (wara Wayang) adalah orang yang beruntung sekali jika dirinya mau dengan tulus melakukan apa yang tersurat dalam bhisma lontar Kala-Purana.

Kelahiran itu dipengaruhi oleh hari dan tata letak benda-benda angkasa, yang secara pasti akan berdampak pada tubuh kita sendiri. Sebab pada dasarnya, Bhuana Agung akan direalisasikan dalam Bhuana Alit, sebab tubuh manusia sendiri merupakan hasil dari perpaduan komponen lima elemen kasar yang datang dari bhuana agung. Karena itu, mustahil bagi kita sebagai mahluk hidup, untuk terlepas dari alam semesta. Sebut saja, jika matahari berada tepat di atas kepala kita, maka tenaga kita akan terkuras dengan cepat. Kelelahan akan datang dengan segera, dan stamina kita akan jauh merosot, maka di saat itulah kita harus mengistirahatkan diri kita. Alasan itu juga yang kita temukan dalam lontar Kala Purana, mengapa seseorang yang melakukan aktifitas disiang bolong (tengai tepet) akan ditadah Kala. Waktu akan menguras energi kita, dan stamina kita menjadi melemah, sebab jam-jam demikian adalah saatnya bagi kita untuk beristirahat.

Berdasarkan itu ada keyakinan kebudayaan masyarakat Bali bahwa mereka yang memiliki hari kelahiran di wara Wayang, maka lakukan seperti apa yang sudah ditentukan. Jangan sekali-kali melawan alam dan waktu, sebab kita sendiri akan dibatasi waktu. Contoh kecil, suatu ketika nanti kita akan mati, dan hanya waktu (kala) yang tahu. Dengan demikian, hidup manusia sejatinya merupakan sebuah jalinan peristiwa, yang entah kapan akan terhenti oleh waktu. Kita melihat ada berbagai macam larangan yang tertera dalam narasi dan jalinan peristiwa di lontar ini. Secara simultan maka ini merupakan bagian dari sebuah pembelajaran etika bagi manusia itu sendiri, sebab hidup dengan tata cara yang baik (etika: baca Tata Susila) akan membawa manusia itu pada sebuah keadaan yang aman.

Dalam lontar ini, tidak diperkenankan untuk membuka atau membiarkan salah satu lubang kompor (bungut paon) terbuka. Ini memberikan perlindungan kepada kita, bahwa kompor itu adalah alat atau sarana untuk memasak dan yang pasti disana adalah tempatnya api. Jika lubang itu terbuka, tanpa ada kegiatan memasak, maka sudah pasti bara api dan bunga percikan api yang kecil-kecil dapat saja diterbangkan angin, dan akhirnya akan mengakibatkan kejadian yang fatal.

Dahulu, orang-orang memasak dengan menggunakan kayu bakar dan menggunakan cangkem paon untuk pekerjaan itu. Sudah dapat dipastikan, selesai memasak, maka bara apinya pasti masih tersisa, dan jika tidak ditutup dengan baik, disanalah bahayanya. Jika ada angin sedikit saja masuk ke dapur, maka api itu bisa terpercik dan mengakibatkan kebakaran yang hebat. Jika hal tersebut terjadi, maka sudah dapat dipastikan, orang itu tadah kala. Dengan demikian, difinisinya dapat berubah sesuai dengan keadaan dan situasi. Apapun bentuk geguat yang terdapat dalam setiap jalinan peristiwa Lontar Kala_Purana, ternyata memiliki sebuah tujuan yang baik untuk keselamatan kita sebagai manusia Bali. Begitu juga dengan adanya perintah tidak boleh mengikat kayu bakar yang ditempatkan di bawah klumpu atau jineng.

Hal ini lebih pada sebuah usaha pencegahan agar jangan sampai binatangbinatang kecil berbahaya seperti lintah, kalajengking, lipan, dan laba-laba beracun bersarang di sana. Sebab mengingat, jika kayu bakar itu diikat di bawah klumpu, maka ini akan menyebabkan kelembaban pada tumpukan kayu, dan keadaan lembab ini mengundang kalajengking, lipan untuk datang dan bersarang di sana.

Terlebih lagi, Jineng atau klumpu itu sendiri merupakan sebuah tempat penyimpanan beras atau padi jaman dahulu. Kemudian di bagian bawahnya adalah tempat orang berteduh atau merebahkan diri setelah bekerja keras seharian. Inilah bahayanya, jika 
seseorang tengah berbaring di sana, kemudian datang kalajengking dan menggigit mereka, maka dengan kata lain, orang itu dinyatakan sudah tadah kala.

\section{KESIMPULAN}

Jadi pada prinsipnya, sebuah jalinan narasi dalam lontar Kala-Purana mengarahkan pembacanya untuk dapat mengertikan sebuah kewaspadaan diri sendiri. Mencoba untuk menenangkan diri dan tidak melakukan tindakan yang bodoh. Dalam kasus ini kita bisa saja melihat bahwa mengapa ketika sandhyakala seseorang dilarang untuk berdebat, atau bertengkar. Ini disebabkan karena jam-jam sarumua seperti ini, tubuh kita sudah masuk pada fase transisi yang labil.

Dengan demikian emosi, seseorang dapat meledak-ledak, dengan cepat dan ini tidak membawa pada sebuah hal yang baik. dengan demikian, Kala dalam perspektif ini merupakan waktu yang mengurung kita sebagai manusia, dan manusia itu sendiri tidak akan pernah dapat menolak waktu itu sendiri. Kapanpun manusia ingin menolak atau melawannya, maka akan ada konsekwensinya.
Satu contoh yang kecil untuk kita renungkan adalah, jika malam hari, maka tubuh manusia harus istirahat total dalam tidur. Ketika seseorang menolak waktu malam hari untuk tidur, ia gunakan untuk bergadang, maka sudah pasti, ia akan mengalami gangguan kesehatan. Paling tidak tekanan darahnya akan menurun drastis. Oleh sebab itulah, mengapa perlu ada sebuah batasan-batasan untuk hidup kita, sebab hidup manusia itu terikat akan waktu secara alami.

\section{DAFTAR PUSTAKA}

Anonim. Lontar Kala Purana. Koleksi Pusat Dokumentasi Provinsi Bali.

Pendit, Nyoman S. 2007. Filsafat Hindu Dharma Sad-Darsana. Denpasar:Pustaka Bali Post

Murni, Dkk. 2009. Darsana. Direktorat Jendral Bimbingan Masyarakat Hindu Departemen Agama

Madja, I Ketut. 2009. Darsana. Institut Hindu Dharma Negeri Denpasar

Ngurah, I Gusti Made. 2006. Buku Pendidikan Agama Hindu Untuk Perguruan Tinggi. Surabaya:Paramita 